Article

\title{
Individual and Regional Characteristics Associated with Maternal Smoking During Pregnancy in Japan: Healthy Parents and Children 21
}

\author{
Tadao Ooka *(D, Yuka Akiyama, Ryoji Shinohara, Hiroshi Yokomichi ${ }^{\mathbb{D}}$ and Zentaro Yamagata \\ Department of Health Sciences, University of Yamanashi, Yamanashi 409-3898, Japan; \\ yukaa@yamanashi.ac.jp (Y.A.); rshinohara@yamanashi.ac.jp (R.S.); hyokomichi@yamanashi.ac.jp (H.Y.); \\ zenymgt@yamanashi.ac.jp (Z.Y.) \\ * Correspondence: tohoka@yamanashi.ac.jp; Tel.: +81-55-273-9566
}

Received: 29 November 2019; Accepted: 23 December 2019; Published: 25 December 2019

\begin{abstract}
Smoking during pregnancy causes various maternal and fetal health problems. Although there are considerable differences in maternal smoking proportions between localities, only a few studies have investigated the effects of regional characteristics on maternal smoking behavior. This study aimed to clarify the association between maternal smoking during pregnancy and individual and regional characteristics. We used data from a large nationwide birth cohort study in Japan that consisted of information on 20,267 women with children aged 3-4 months. The multilevel regression model was used to examine the association between smoking behavior during pregnancy and individual and regional characteristics. On multilevel analysis, late birth order, young age of the mother at birth, low birth weight, low economic status, husband's smoking during pregnancy, maternal alcohol consumption during pregnancy, absence of a pregnancy counselor, and lack of participation in local events for childrearing were significantly associated with maternal smoking behavior during pregnancy at the individual level. Meanwhile, a high unemployment rate and a high number of nurseries were significantly associated with maternal smoking behavior during pregnancy at the regional level. In conclusion, we showed the relation between maternal smoking during pregnancy and the individual- and regional-level characteristics.
\end{abstract}

Keywords: smoking; cigarettes; pregnancy; social capital; Healthy Parents and Children 21; Japan

\section{Introduction}

Smoking during pregnancy has been suggested to cause various health problems to both the mother and the baby. It leads to low birth weight [1] and retarded intrauterine growth [1-3] and adversely affects the child's growth after birth [4]. The recently proposed concept of Development Origins of Health and Disease suggests that child development and even their adulthood may be affected by their mothers' smoking during pregnancy [5]. The World Health Organization has reported a recent increase in smoking rates among women and projected the average women's smoking rate to increase to $20 \%$ by 2025 [6]. The prevalence of female smokers is the highest in the European and Americas regions.

In Japan, the smoking rate of women has leveled at around 9\% in the last 10 years (National Health and Nutrition Survey in Japan; 2014), and thus, new measures to reduce the smoking rate among women, particularly those who are pregnant, are needed. Though various programs against smoking during pregnancy have been implemented in Japan, the maternal smoking rate during pregnancy has not markedly declined in recent years. Furthermore, approximately $40 \%$ of women resume smoking after temporary cessation during pregnancy (from the survey and research project of the Health Promotion Association in Japan; 2013). 
Considering that there are significant differences in smoking rates by region, there is a considerable possibility of causing maternal smoking behavior by some characteristics of their living area. Therefore, the effect of an individual intervention for smoking cessation will be poor in the community with a high smoking rate because the environment of pregnant women does not encourage smoking cessation [7]. In addition, smoking pregnant women have difficulty trying to stop smoking because of several reasons including restrictions on medication use [8], and thus, community support is crucial for smoking cessation [9]. Further, countermeasures with a framework including social capital are also necessary [10].

Previous studies have shown some characteristics in pregnant women to influence smoking behavior; these include education levels [11], maternal parity [12], relationships with partners [13], and smoking among the partner or parents [14]. Conversely, a European study [10] found certain regional characteristics including regional socioeconomic status (SES) and ethnicity to be associated with maternal smoking behavior.

Smoking during pregnancy is considered to be an important factor in the association between low SES and negative infancy outcomes $[15,16]$. A low level of education and economics status, unhealthy behavior of family members, and poor relationships with close people predispose pregnant women to pursue habits that are inappropriate for childcare, including maternal smoking; this results in negative infancy outcomes. No studies have examined whether the regional SES plays an important role in Asia. It is therefore necessary to determine whether the same causal association exists in this area. It is also necessary to verify whether the influence of individual factors changes depending on regional factors, particularly those related to economic status. This study aimed to clarify the effects of regional factors on smoking during pregnancy. Towards this goal, we examined measures that might influence smoking behavior not only at the individual but also at the community level. Further, we examined both individual- and regional-level factors that might influence smoking behavior during pregnancy.

\section{Materials and Methods}

\subsection{Study Participants}

This study used data from the final evaluation of Healthy Parents and Children 21. Healthy Parents and Children 21 was a national campaign of the Ministry of Health, Labor and Welfare of Japan aimed to improve the health status of mothers and children in Japan. The campaign started in April 2001 and ended in March 2015. A final evaluation of this campaign was performed in 2013. This evaluation was conducted by approximately 75,600 caregivers who implemented health checks for 3- or 4-month-old, 18-month-old, and 3-year-old children in 472 municipalities assigned for each city (Japan is divided into 47 prefectures. Each prefecture comprises numerous municipalities, with 1,719 in total.)

\subsection{Data Collection}

A total of 20,729 women with children aged 3 or 4 months old participated in this evaluation. We requested them to answer self-administered questionnaires sent by mail and gathered them when they came for a health check for their child. Of the 23,224 women who received the questionnaire, 20,729 women responded. Among them, 20,276 with available data were included in the analysis. The participant selection flow chart is shown in Figure 1.

The self-administered questionnaire comprised 40 questions that mainly evaluated the mothers' parenting environment during pregnancy. All questions were answered with a yes or no or a numbered selection. 


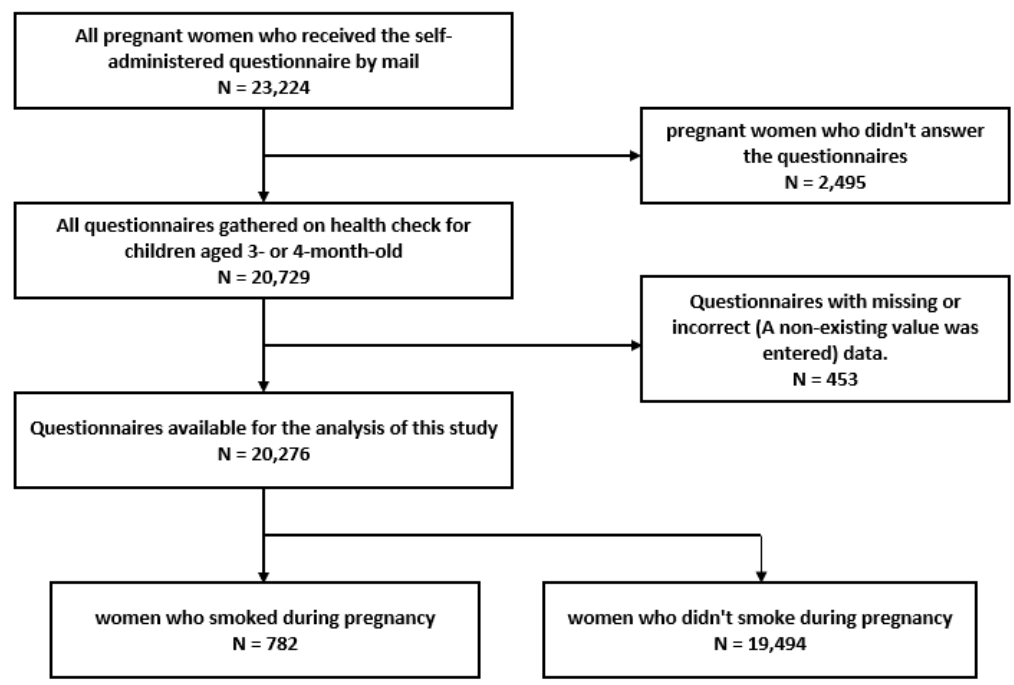

Figure 1. Selection flow of smoking pregnant women.

\subsection{Exposure Variables}

We performed a single regression analysis for all questions to evaluate the influence of individual factors on pregnant women. There were 18 questions that were significantly related:

1. "How many children do you have?"

2. "How old were you at the time of your childbirth?"

3. "How much did your child weigh at birth?"

4. "How do you feel about your current economic status?"

5. "Was your husband smoking during your pregnancy?"

6. "Were you drinking during pregnancy?"

7. "Were there any counsellors during and after your pregnancy?"

8. "Have you participated in local events for child-raising?"

9. "Do you want to have the next child?"

10. "Did you have any unaddressed problems during your pregnancy or childbirth?"

11. "Did you smoke when you found out you were pregnant?"

12. "Was your husband smoking when you found out that you were pregnant?"

13. "Did you feel the effects of the Japanese maternity mark during pregnancy?"

14. "Does anyone speak to you on the road when you go out with your child?"

15. "When you put your child to bed, do you make him/her lie on his/her back?

16. "Do you breastfeed your child?"

17. "Are you currently smoking?"

18. "Is your husband currently smoking?"

To avoid obvious multicollinearity, questions regarding maternal and paternal smoking behavior were limited to the period of pregnancy (6 and 7). We excluded questions with too many options (15 options exist on question 10). We also excluded questions that would not have a direct effect on maternal smoking behavior (13-16), based on previous studies [7,9-14,17-28]. Finally, we selected 9 questions (1-9) as individual variables. We also implemented a stepwise analysis of these questions and chose eight questions as explanatory variables to regulate the individual-level model (See in Table 1).

For regional factors, we used 11 sociodemographic factors from the national database of the Japanese statistics bureau (e-stat, 2010; Statistics Bureau, Ministry of Internal Affairs and Communications, Japan). Single regression analysis of these factors identified five significant 
variables, namely, unemployment rate, birthrate, number of nurseries, financial strength index (FSI), and population density; and they were selected as regional factors.

Table 1. Summary of Variable Definitions.

\begin{tabular}{|c|c|}
\hline Variable Name & Survey Questions, Coding, and Methods of Calculation \\
\hline Maternal smoke & “Were you smoking during pregnancy?” (1 = No, 2= Yes). \\
\hline \multicolumn{2}{|l|}{ First level variables $(\mathrm{N}=20276)$} \\
\hline Mother's age at birth & $\begin{array}{l}\text { "How old were you at the time of your childbirth?" }(1=19 \text { years old or younger, } \\
2=20 \text { to } 24 \text { years old, } 3=25 \text { to } 29 \text { years old, } 4=30 \text { to } 34 \text { years old, } 5=35 \text { to } 39 \\
\text { years old, } 6=40 \text { years old or older })\end{array}$ \\
\hline Economic status (subjective) & $\begin{array}{l}\text { "How do you feel about your current economic status?" }(1=\text { Very good, } 2=\text { good, } \\
3=\text { normal, } 4=\text { poor, } 5 \text { = very poor })\end{array}$ \\
\hline Husband's smoking habit during pregnancy & "Was your husband smoking during your pregnancy?" (1 = No, 2 = Yes). \\
\hline \multicolumn{2}{|l|}{ Second level variables $(\mathrm{N}=420)$} \\
\hline Unemployment rate & (number of unemployed people in the region)/(working population in the region) \\
\hline Birthrate & annual number of birthchildren per 1000 population in the region. \\
\hline Number of nursery & $\begin{array}{l}\text { number of nurseries per } 1000 \text { children population (under five years-old) in the } \\
\text { region. }\end{array}$ \\
\hline Financial Strength Index $(\mathrm{FSI}) *$ & $\begin{array}{l}\text { (standard financial revenues in the region)/(amount of basic fiscal demand in the } \\
\text { region) }\end{array}$ \\
\hline Population density & (population of the region)/(extent of inhabitable area in the region $\left.\left(\mathrm{km}^{2}\right)\right)$ \\
\hline
\end{tabular}

\subsection{Outcome Variable}

The main outcome variable was smoking during pregnancy. This was evaluated using the question "Were you smoking during pregnancy?" and we determined the mothers' smoking habit during pregnancy from the answer to this question. We evaluated the effects of individual factors on pregnant mothers and regional factors in their living area. The score of all regional factors was divided into quartiles (Q1-4). The definition of each individual and regional factor is described in Table 1.

\subsection{Statistical Analysis}

Multilevel logistic models were used to investigate the effect of regional factors on maternal smoking behavior during pregnancy. In this model, individual factors of pregnant women were used as the primary level, and regional factors of their living areas were used as the secondary level. Multilevel logistic regression analysis with random intercept models was employed to demonstrate the effect of regional factors on pregnant women. The estimated multilevel regression model is formally expressed as:

Individual-level model:

$$
\begin{aligned}
& \text { Yij }=\beta 0 j+\beta 1 \text { (Birth order) }+\beta 2 \text { (Mother's age) }+\beta 3 \text { (Birth weight) } \\
& +\beta 4 \text { (Economic status) }+\beta 5 \text { (Husband's smoking })+\beta 6 \text { (Drinking habit) } \\
& +\beta 7 \text { (Existence of counselor })+\beta 8 \text { (Participation in local events })+ \text { eij }
\end{aligned}
$$

where $\mathrm{Yij}_{\mathrm{j}}$ is the frequency of maternal smoking during pregnancy for the respondent $\mathrm{i}$ in the region $\mathrm{j}$. 
Regional-level direct effects model:

$$
\begin{aligned}
& \beta 0 \mathrm{j}=\gamma 00+\gamma 01 \text { (Unemployment rate) }+\gamma 02 \text { (Birthrate) }+\gamma 03 \text { (Number of nursery) } \\
& +\gamma 04 \text { (Financial Strength Index })+\gamma 05 \text { (Population density) }+\mathrm{u} 0 \mathrm{j}
\end{aligned}
$$

We use generalized linear mixed-effects models with adaptive Gauss Hermite quadrature. These models were fitted with the help of SAS PROC GLIMMIX. (The GLIMMIX procedure fits statistical models to data with correlations or nonconstant variability and where the response is not necessarily normally distributed.) All analyses were conducted using SAS version 9.4 (SAS Institute Inc., Cary, NC, USA).

\subsection{Ethical Considerations}

This study was approved by the Ethics Committee of the University of Yamanashi (identification code: No. 1119). The participants in Healthy Parents and Children 21 were informed that participation in this study was voluntary, and completion and return of the self-administered questionnaire indicated their consent to participate in this study.

\section{Results}

Smoking was prevalent in more than $10 \%$ of women with very poor economic status $(11.87 \%)$, four or more children (13.43\%), and drinking habit during pregnancy $(15.25 \%)$. Table 2 shows the prevalence of smoking women according to each individual- and regional-level variable.

Several variables were significantly associated with maternal smoking during pregnancy. The results of single logistic regression analysis for each variable at the individual and regional level are shown in Table 3. Figure 2 shows the coefficient of correlation between each regional variable,

\begin{tabular}{|c|c|c|c|c|c|}
\hline & $\begin{array}{l}\text { Unemploy } \\
\text { ment rate }\end{array}$ & Birthrate & $\begin{array}{c}\text { Number of } \\
\text { nursery }\end{array}$ & $\begin{array}{c}\text { Financial } \\
\text { Strength } \\
\text { Index }\end{array}$ & $\begin{array}{c}\text { Population } \\
\text { density }\end{array}$ \\
\hline $\mathrm{N}$ & 20,276 & 20,276 & 20,276 & 20,276 & 20,276 \\
\hline $\begin{array}{l}\text { Unemploy } \\
\text { ment rate }\end{array}$ & & $\begin{array}{l}0.044 \\
<0.0001\end{array}$ & $\begin{array}{l}-0.191 \\
<0.0001\end{array}$ & $\begin{array}{l}0.001 \\
<0.0001\end{array}$ & $\begin{array}{c}0.33 \\
<0.0001\end{array}$ \\
\hline Birthrate & & & $\begin{array}{l}-0.421 \\
<0.0001\end{array}$ & $\begin{array}{l}0.518 \\
<0.0001\end{array}$ & $\begin{array}{c}0.443 \\
<0.0001\end{array}$ \\
\hline $\begin{array}{c}\text { Number of } \\
\text { nursery }\end{array}$ & & & & $\begin{array}{l}-0.653 \\
<0.0001\end{array}$ & $\begin{array}{l}-0.636 \\
<0.0001\end{array}$ \\
\hline $\begin{array}{l}\text { Financial } \\
\text { Strength } \\
\text { Index }\end{array}$ & & & & & $\begin{array}{l}0.731 \\
<0.0001\end{array}$ \\
\hline $\begin{array}{c}\text { Population } \\
\text { density }\end{array}$ & & & & & \\
\hline
\end{tabular}
and Figure A1 shows the coefficient of correlation between each individual variable.

Figure 2. Coefficient of correlation between sociological variables.

In multilevel analyses (Table 4), Model 1 is an analysis of intercept, while Model 2 is a logistic regression analysis only with individual factors in consideration of regional level nesting. The characteristics of individual pregnant women that were significantly associated with smoking are birth of third child or more, age at birth of 24 years old or younger, infant birth weight of $2500 \mathrm{~g}$ or less, subjective economic status of poor or very poor, the husband's smoking during pregnancy, maternal drinking habit during pregnancy, absence of counselor, and no participation in local events for childrearing. The most common group of each individual variable was selected as a reference for the analysis. 
Table 2. Individual and regional variables.

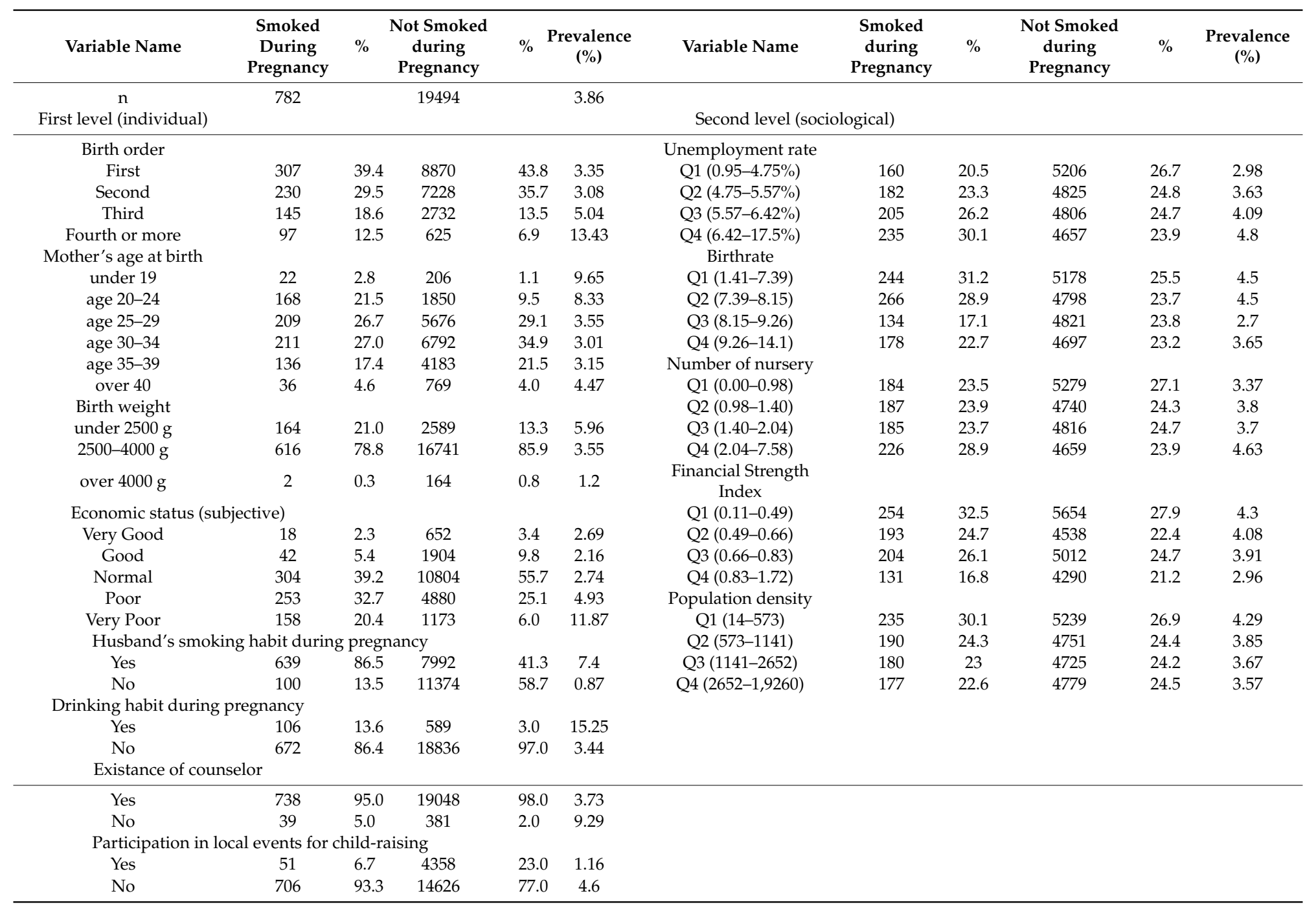


Table 3. Single logistic regression analyses.

\begin{tabular}{|c|c|c|c|c|c|c|c|}
\hline Variables & OR & \multicolumn{2}{|c|}{$95 \% \mathrm{CI}$} & Variables & OR & \multicolumn{2}{|c|}{$95 \% \mathrm{CI}$} \\
\hline First level (individual) & & & & Second level (sociological) & & & \\
\hline Birth order & & & & Unemployment rate & & & \\
\hline First & ref. & & & Q1 (0.95-4.75\%) & ref. & & \\
\hline Second & 0.919 & 0.773 & 1.094 & Q2 (4.75-5.57\%) & 1.227 & 0.989 & 1.523 \\
\hline Third & 1.533 & 1.253 & 1.877 & Q3 (5.57-6.42\%) & 1.388 & 1.125 & 1.713 \\
\hline Fourth or more & 4.485 & 3.52 & 5.714 & Q4 (6.42-17.5\%) & 1.642 & 1.338 & 2.015 \\
\hline Mother's age at birth & & & & Birthrate & & & \\
\hline under 19 & 3.438 & 2.169 & 5.448 & Q1 (1.41-7.39) & ref. & & \\
\hline age $20-24$ & 2.923 & 2.372 & 3.603 & Q2 (7.39-8.15) & 1 & 0.831 & 1.203 \\
\hline age $25-29$ & 1.185 & 0.976 & 1.44 & Q3 (8.15-9.26) & 0.59 & 0.476 & 0.731 \\
\hline age $30-34$ & ref. & & & Q4 (9.26-14.1) & 0.804 & 0.66 & 0.98 \\
\hline age $35-39$ & 1.047 & 0.841 & 1.303 & Number of nursery & & & \\
\hline over 40 & 1.507 & 1.05 & 2.163 & Q1 (0.00-0.98) & ref. & & \\
\hline Birth weight & & & & Q2 (0.98-1.40) & 1.132 & 0.92 & 1.392 \\
\hline under $2500 \mathrm{~g}$ & 1.722 & 1.442 & 2.055 & Q3 (1.40-2.04) & 1.102 & 0.895 & 1.357 \\
\hline $2500-4000 \mathrm{~g}$ & ref. & & & Q4 (2.04-7.58) & 1.392 & 1.141 & 1.698 \\
\hline over $4000 \mathrm{~g}$ & 0.331 & 0.082 & 1.34 & Financial Strength Index & & & \\
\hline \multicolumn{2}{|c|}{ Economic status (subjective) } & & & Q1 $(0.11-0.49)$ & ref. & & \\
\hline Very Good & 0.981 & 0.606 & 1.589 & Q2 (0.49-0.66) & 0.947 & 0.782 & 1.146 \\
\hline Good & 0.784 & 0.566 & 1.086 & Q3 (0.66-0.83) & 0.906 & 0.751 & 1.094 \\
\hline Normal & ref. & & & $\widehat{\mathrm{Q}} 4(0.8-1.72)$ & 0.68 & 0.549 & 0.843 \\
\hline Poor & 1.843 & 1.554 & 2.184 & Population density & & & \\
\hline Very Poor & 4.788 & 3.914 & 5.856 & Q1 (14-573) & ref. & & \\
\hline \multicolumn{3}{|c|}{ Husband's smoking habit during pregnancy } & & Q2 (573-1141) & 0.892 & 0.733 & 1.084 \\
\hline Yes & 9.093 & 7.351 & 11.248 & Q3 (1141-2652) & 0.849 & 0.697 & 1.035 \\
\hline No & ref. & & & $\widehat{Q 4}(2652-1,9260)$ & 0.826 & 0.677 & 1.007 \\
\hline \multicolumn{8}{|c|}{ Drinking habit during pregnancy } \\
\hline Yes & 1.605 & 1.373 & 1.876 & & & & \\
\hline No & ref. & & & & & & \\
\hline \multicolumn{8}{|c|}{ Existance of counselor } \\
\hline Yes & ref. & & & & & & \\
\hline $\mathrm{No}$ & 2.313 & 1.684 & 3.176 & & & & \\
\hline \multicolumn{8}{|c|}{ Participation in local events for child-raising } \\
\hline Yes & ref. & & & & & & \\
\hline No & 4.125 & 3.098 & 5.491 & & & & \\
\hline
\end{tabular}


Table 4. Multilevel logistic regression analyses (Model 1-Model 4).

\begin{tabular}{|c|c|c|c|c|c|c|c|c|c|c|}
\hline \multirow{2}{*}{ Variables } & \multirow{2}{*}{ Model 1} & \multicolumn{3}{|c|}{ Model 2} & \multicolumn{3}{|c|}{ Model 3-1 } & \multicolumn{3}{|c|}{ Model 3-2 } \\
\hline & & OR & \multicolumn{2}{|c|}{$95 \%$ CI } & OR & \multicolumn{2}{|c|}{$95 \% \mathrm{CI}$} & OR & \multicolumn{2}{|c|}{$95 \% \mathrm{CI}$} \\
\hline \multicolumn{11}{|l|}{ Birth order $\beta 1$} \\
\hline First & & ref. & & & ref. & & & ref. & & \\
\hline Second & & 1.023 & 0.842 & 1.243 & 1.026 & 0.845 & 1.247 & 1.023 & 0.842 & 1.243 \\
\hline Third & & 1.506 & 1.187 & 1.911 & 1.508 & 1.189 & 1.912 & 1.507 & 1.188 & 1.911 \\
\hline Fourth or more & & 3.104 & 2.302 & 4.186 & 3.076 & 2.284 & 4.142 & 3.068 & 2.277 & 4.135 \\
\hline \multicolumn{11}{|c|}{ Mother's age at birth $\beta 2$} \\
\hline under 19 & & 3.465 & 2.063 & 5.82 & 3.538 & 2.109 & 5.937 & 3.478 & 2.072 & 5.837 \\
\hline age $20-24$ & & 2.351 & 1.84 & 3.003 & 2.354 & 1.843 & 3.006 & 2.339 & 1.831 & 2.988 \\
\hline age $25-29$ & & 1.156 & 0.933 & 1.433 & 1.164 & 0.94 & 1.443 & 1.155 & 0.932 & 1.432 \\
\hline age $30-34$ & & ref. & & & ref. & & & ref. & & \\
\hline age $35-39$ & & 0.981 & 0.768 & 1.252 & 0.992 & 0.777 & 1.267 & 0.978 & 0.766 & 1.249 \\
\hline over 40 & & 1.287 & 0.847 & 1.953 & 1.263 & 0.832 & 1.918 & 1.309 & 0.863 & 1.985 \\
\hline \multicolumn{11}{|l|}{ Birth weight $\beta 3$} \\
\hline under $2500 \mathrm{~g}$ & & 1.611 & 1.319 & 1.969 & 1.614 & 1.321 & 1.972 & 1.608 & 1.316 & 1.964 \\
\hline $2500-4000 \mathrm{~g}$ & & ref. & & & ref. & & & ref. & & \\
\hline over $4000 \mathrm{~g}$ & & 0.202 & 0.029 & 1.382 & 0.199 & 0.029 & 1.372 & 0.21 & 0.031 & 1.433 \\
\hline \multicolumn{11}{|c|}{ Economic status (subjective) $\beta 4$} \\
\hline Very Good & & 0.754 & 0.424 & 1.343 & 0.75 & 0.421 & 1.334 & 0.761 & 0.428 & 1.354 \\
\hline Good & & 0.872 & 0.613 & 1.242 & 0.887 & 0.623 & 1.262 & 0.869 & 0.611 & 1.238 \\
\hline Normal & & ref. & & & ref. & & & ref. & & \\
\hline Poor & & 1.434 & 1.191 & 1.727 & 1.436 & 1.192 & 1.729 & 1.438 & 1.194 & 1.731 \\
\hline Very Poor & & 2.462 & 1.947 & 3.114 & 2.473 & 1.957 & 3.126 & 2.465 & 1.949 & 3.116 \\
\hline \multicolumn{11}{|c|}{$\begin{array}{l}\text { Husband's smoking habit during } \\
\text { pregnancy } \beta 5\end{array}$} \\
\hline Yes & & 7.361 & 5.882 & 9.213 & 7.367 & 5.887 & 9.219 & 7.333 & 5.859 & 9.178 \\
\hline No & & ref. & & & ref. & & & ref. & & \\
\hline \multicolumn{11}{|c|}{ Drinking habit during pregnancy $\beta 6$} \\
\hline Yes & & 3.997 & 3.066 & 5.21 & 3.988 & 3.063 & 5.193 & 3.937 & 3.021 & 5.132 \\
\hline No & & ref. & & & ref. & & & ref. & & \\
\hline \multicolumn{11}{|c|}{ Existence of counselor $\beta 7$} \\
\hline Yes & & ref. & & & ref. & & & ref. & & \\
\hline No & & 2.082 & 1.411 & 3.073 & 2.048 & 1.39 & 3.017 & 2.057 & 1.394 & 3.034 \\
\hline
\end{tabular}


Table 4. Cont.

\begin{tabular}{|c|c|c|c|c|c|c|c|c|c|c|c|c|}
\hline \multirow{2}{*}{ Variables } & \multirow{2}{*}{\multicolumn{3}{|c|}{ Model 1}} & \multicolumn{3}{|c|}{ Model 2} & \multicolumn{3}{|c|}{ Model 3-1 } & \multicolumn{3}{|c|}{ Model 3-2 } \\
\hline & & & & OR & \multicolumn{2}{|c|}{$95 \%$ CI } & OR & \multicolumn{2}{|c|}{$95 \% \mathrm{CI}$} & OR & \multicolumn{2}{|c|}{$95 \% \mathrm{CI}$} \\
\hline Yes & & & & ref. & & & ref. & & & ref. & & \\
\hline No & & & & 3.232 & 2.368 & 4.411 & 3.143 & 2.303 & 4.29 & 3.236 & 2.371 & 4.415 \\
\hline \multicolumn{13}{|l|}{ Second level (sociological) } \\
\hline \multicolumn{13}{|l|}{ Unemployment rate $\gamma 01$} \\
\hline Q1 $(0.95-4.75 \%)$ & & & & & & & ref. & & & & & \\
\hline Q2 (4.75-5.57\%) & & & & & & & 1.062 & 0.822 & 1.373 & & & \\
\hline Q3 (5.57-6.42\%) & & & & & & & 1.41 & 1.102 & 1.805 & & & \\
\hline Q4 (6.42-17.5\%) & & & & & & & 1.477 & 1.16 & 1.88 & & & \\
\hline \multicolumn{13}{|l|}{ Birthrate $\gamma 02$} \\
\hline Q1 (1.41-7.39) & & & & & & & & & & ref. & & \\
\hline Q2 (7.39-8.15) & & & & & & & & & & 1.079 & 0.861 & 1.354 \\
\hline Q3 (8.15-9.26) & & & & & & & & & & 0.714 & 0.556 & 0.917 \\
\hline Q4 (9.26-14.1) & & & & & & & & & & 0.972 & 0.767 & 1.233 \\
\hline \multicolumn{13}{|l|}{ Fixed effect (level1) } \\
\hline Intercept $\gamma 00$ & \multicolumn{3}{|c|}{-3.28} & \multicolumn{3}{|c|}{-6.41} & \multicolumn{3}{|c|}{-6.59} & \multicolumn{3}{|c|}{-6.34} \\
\hline \multicolumn{13}{|l|}{ Random parameter (level2) } \\
\hline Between community $\mathrm{u} 0 \mathrm{j}$ & \multirow{2}{*}{\multicolumn{3}{|c|}{$\begin{array}{c}0.158 \\
6608\end{array}$}} & \multicolumn{3}{|c|}{0.092} & \multicolumn{3}{|c|}{0.053} & \multicolumn{3}{|c|}{0.065} \\
\hline AIC & & & & \multicolumn{3}{|c|}{4981} & & 4972 & & & 4976 & \\
\hline Variables & \multicolumn{3}{|c|}{ Model 3-3 } & & Iodel 3 & & & lodel 3 & & & Model 4 & \\
\hline & OR & $95 \%$ & & OR & & & OR & & & OR & & CI \\
\hline First level (individual) & & & & & & & & & & & & \\
\hline Birth order $\beta 1$ & & & & & & & & & & & & \\
\hline First & ref. & & & ref. & & & ref. & & & ref. & & \\
\hline Second & 1.017 & 0.837 & 1.236 & 1.021 & 0.84 & 1.24 & 1.025 & 0.843 & 1.245 & 1.022 & 0.841 & 1.241 \\
\hline Third & 1.49 & 1.174 & 1.891 & 1.501 & 1.182 & 1.905 & 1.512 & 1.191 & 1.92 & 1.489 & 1.174 & 1.889 \\
\hline Fourth or more & 3.045 & 2.256 & 4.109 & 3.102 & 2.299 & 4.186 & 3.124 & 2.315 & 4.216 & 2.997 & 2.223 & 4.04 \\
\hline Mother's age at birth $\beta 2$ & & & & & & & & & & & & \\
\hline under 19 & 3.46 & 2.06 & 5.809 & 3.457 & 2.058 & 5.807 & 3.483 & 2.073 & 5.851 & 3.602 & 2.148 & 6.039 \\
\hline age $20-24$ & 2.335 & 1.828 & 2.984 & 2.354 & 1.843 & 3.008 & 2.359 & 1.847 & 3.015 & 2.338 & 1.831 & 2.985 \\
\hline
\end{tabular}


Table 4. Cont.

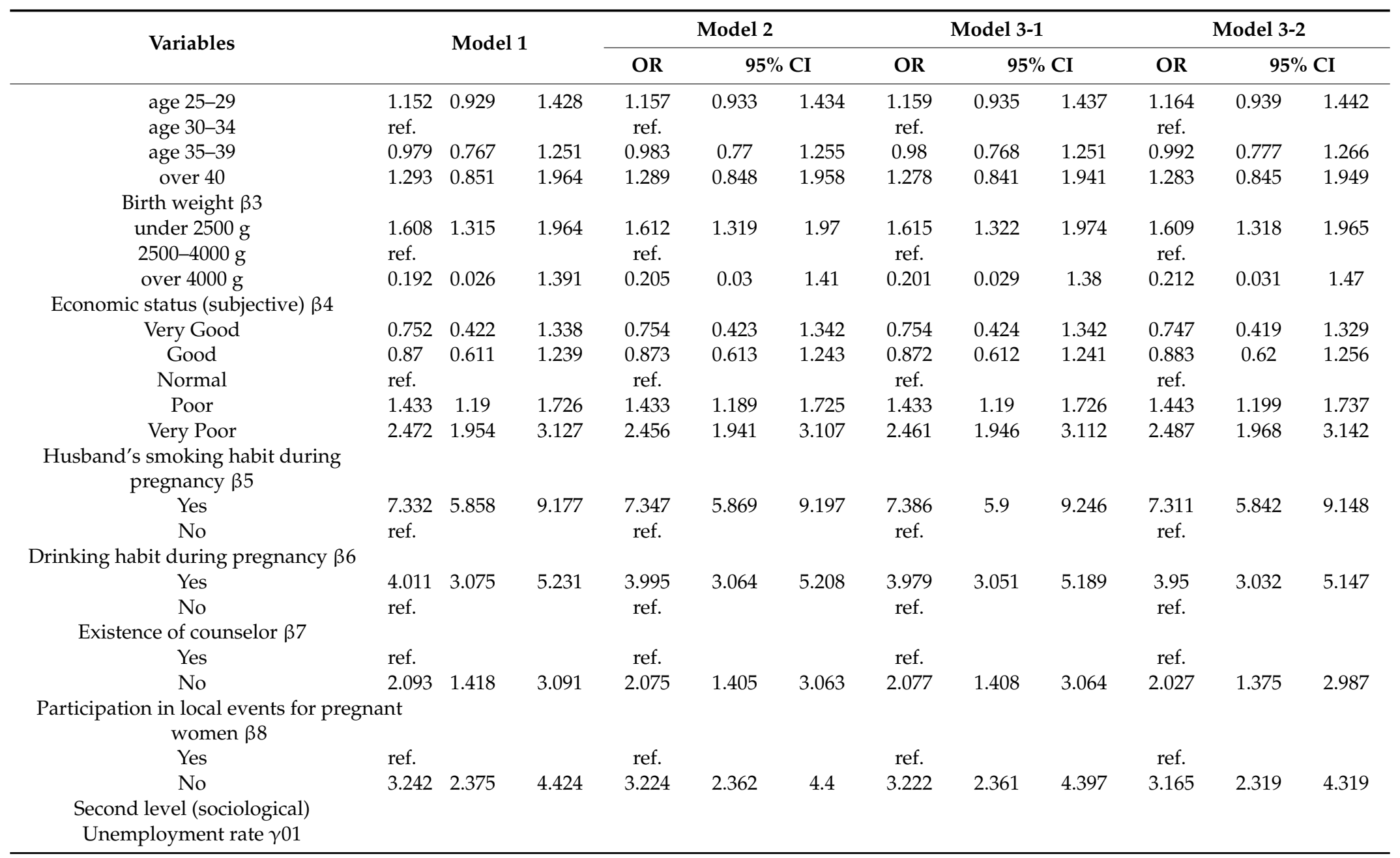


Table 4. Cont.

\begin{tabular}{|c|c|c|c|c|c|c|c|c|c|c|c|c|}
\hline \multirow{2}{*}{ Variables } & \multirow{2}{*}{\multicolumn{3}{|c|}{ Model 1}} & \multicolumn{3}{|c|}{ Model 2} & \multicolumn{3}{|c|}{ Model 3-1 } & \multicolumn{3}{|c|}{ Model 3-2 } \\
\hline & & & & \multirow[t]{2}{*}{ OR } & \multicolumn{2}{|c|}{$95 \% \mathrm{CI}$} & \multirow[t]{2}{*}{ OR } & \multicolumn{2}{|c|}{$95 \% \mathrm{CI}$} & OR & \multicolumn{2}{|c|}{$95 \% \mathrm{CI}$} \\
\hline & & & & & & & & & & & & \\
\hline Q2 (4.75-5.57\%) & & & & & & & & & & 1.001 & 0.779 & 1.287 \\
\hline Q3 $(5.57-6.42 \%)$ & & & & & & & & & & 1.439 & 1.118 & 1.852 \\
\hline Q4 (6.42-17.5\%) & & & & & & & & & & 1.481 & 1.147 & 1.914 \\
\hline \multicolumn{13}{|l|}{ Birthrate $\gamma 02$} \\
\hline Q1 (1.41-7.39) & & & & & & & & & & ref. & & \\
\hline Q2 (7.39-8.15) & & & & & & & & & & 0.967 & 0.763 & 1.226 \\
\hline Q3 (8.15-9.26) & & & & & & & & & & 0.638 & 0.488 & 0.834 \\
\hline Q4 $(9.26-14.1)$ & & & & & & & & & & 0.915 & 0.696 & 1.203 \\
\hline \multicolumn{13}{|l|}{ Number of nursery $\gamma 03$} \\
\hline Q1 (0.00-0.98) & ref. & & & & & & & & & ref. & & \\
\hline Q2 (0.98-1.40) & 1.112 & 0.861 & 1.435 & & & & & & & 1.134 & 0.893 & 1.441 \\
\hline Q3 (1.40-2.04) & 0.967 & 0.746 & 1.252 & & & & & & & 1.068 & 0.812 & 1.404 \\
\hline Q4 $(2.04-7.58)$ & 1.185 & 0.927 & 1.517 & & & & & & & 1.406 & 1.044 & 1.894 \\
\hline \multicolumn{13}{|l|}{ Financial Strength Index $\gamma 04$} \\
\hline Q1 $(0.11-0.49)$ & & & & ref. & & & & & & ref. & & \\
\hline Q2 (0.49-0.66) & & & & 1.039 & 0.82 & 1.318 & & & & 1.155 & 0.882 & 1.511 \\
\hline Q3 $(0.66-0.83)$ & & & & 1.122 & 0.889 & 1.417 & & & & 1.311 & 0.977 & 1.76 \\
\hline $\mathrm{Q} 4(0.83-1.72)$ & & & & 0.899 & 0.688 & 1.173 & & & & 1.151 & 0.805 & 1.646 \\
\hline \multicolumn{13}{|l|}{ Population density $\gamma 05$} \\
\hline Q1 (14-573) & & & & & & & ref. & & & ref. & & \\
\hline Q2 (573-1141) & & & & & & & 1.051 & 0.828 & 1.334 & 0.968 & 0.744 & 1.258 \\
\hline Q3 (1141-2652) & & & & & & & 1.053 & 0.824 & 1.346 & 0.984 & 0.71 & 1.363 \\
\hline Q4 $(2652-19,260)$ & & & & & & & 1.094 & 0.852 & 1.405 & 1.032 & 0.733 & 1.452 \\
\hline \multicolumn{13}{|l|}{ Fixed effect (level1) } \\
\hline Intercept $\gamma 00$ & & -6.472 & & & -6.431 & & & -6.461 & & & -6.700 & \\
\hline \multicolumn{13}{|l|}{ Random parameter (level2) } \\
\hline Between community u0j & & 0.089 & & & 0.092 & & & 0.089 & & & 0.037 & \\
\hline AIC & & 4983 & & & 4985 & & & 4987 & & & 4974 & \\
\hline
\end{tabular}


Model 3-1 to Model 3-5 are the results of the multilevel analysis with individual factors of pregnant women as the primary level and regional factors as the secondary level. The first quantile of each regional variable was selected for reference in the analysis. Unemployment rate was significantly associated with maternal smoking on Q3 (OR: 1.41, 95\% confidence interval (CI): 1.102-1.805) and Q4 (OR: 1.477, 95\% CI: 1.160-1.880). In Model 4, which is a multilevel analysis of all individual variables and all regional variables, the following were significantly associated with maternal smoking: birthrate on Q3 (OR: 0.638 , 95\% CI: 0.488-0.834), number of nursery on Q4 (OR: 1.406, 95\% CI: 1.044-1.894), and unemployment rate on Q3 (OR: 1.439, 95\% CI: 1.118-1.852) and Q4 (OR: 1.481, 95\% CI: 1.147-1.914). As shown in Table A1, we conducted a stepwise analysis of regional variables and selected three as explanatory variables to regulate the sociological-level model. The number of nursery on Q4 was not significantly associated with maternal smoking in Model 4.

\section{Discussion}

In this study, we revealed the individual and the regional factors associated with maternal smoking by using individual data from a large national survey and regional data from the national statistics bureau. With respect to individual characteristics, all individual characteristics analyzed in this study were significantly associated with maternal smoking. With respect to regional factors, adjusted multilevel analyses revealed that unemployment rate, birthrate, and number of nurseries were significantly associated with maternal smoking behavior. These analyses indicated that maternal smoking behavior varies depending on regional characteristics.

The association of some individual factors on maternal smoking behavior has already been reported in previous studies $[7,12,19-21,23,24]$. Although most previous studies were conducted in Western countries, similar results in this Japanese study suggest that these factors are not affected by the living environment or ethnic differences. Smoking pregnant women were particularly prevalent in groups where the birth order of the expected child was at least the fourth, the mother was 19 years of age or younger, and the subjective economic situation was very poor. These results will serve to identify the group in particular need of smoking countermeasures in Japan. In addition, we newly showed that the existence of consultation partners and participation in local events for childrearing have a significant relation on their behavior. Both elements are related to loneliness, and it has been suggested in past systematic reviews that loneliness is related to smoking [29].

Regional factors in this study sufficiently adjusted our multilevel model with individual factors when we look at the small value of the random intercept of Model 4. Particularly, the unemployment rate was strongly related to the maternal smoking behavior. A Swedish study [10] has shown that regional economic conditions are related to maternal smoking during pregnancy. In this study, we considered unemployment rate and the Financial Strength Index (FSI) as regional factors related to economic condition, and only the unemployment rate was significantly associated with maternal smoking. The FSI indicates the wealth of the municipality itself, and the abundance of municipality does not mean the richness of the local residents, while high unemployment rates are apparently related to worse economic conditions.

The unemployment rate is also known to be related to the difficulty in smoking cessation [30], type 2 diabetes [31], and participation rate in health checks [32]. These factors are also known to be similarly related to the social capital of the regions [33-35]. Social capital is the network of relationships in a society based on trust in others, trust in the region they live in, and social participation. Ref. [36] A previous study in Japan showed that a low level of social capital in the region is associated with a high unemployment rate [37]. Considering these studies, a high unemployment rate in the region may badly affect the level of social capital, and that may lead to adverse effects on pregnant women's behavior. To clarify these mechanisms, further studies about the relation between social capital and smoking habit among pregnant women should be conducted.

A high number of nursery is also related to a high maternal smoking rate in Table 4. In areas with fewer children and aging populations, the number of nursery per child population is especially 
greater than that in other regions in Japan (Ministry of Health, Labour and Welfare Survey in Japan; 2017). Existing few childrearing events and the loneliness resulting from the small number of women around the same age may increase maternal smoking rate. However, considering the relatively high correlation between the number of nurseries with FSI and population density (as seen in Figure 2), the relationship between the number of nurseries and maternal smoking may have been influenced by these confounding factors. The relationship between maternal smoking and the FSI or population density may have also been obscured by these confounding factors. Residual confounding may have persisted on multiple adjusted levels, as the random parameter in model 4 was not near zero; this may be adjusted with the education level, which we could not include in this study.

In view of the above findings, in areas where the unemployment rate is high or the number of children is very low, the development of a child-rearing environment may play an important role in preventing maternal smoking; this includes encouraging participation in child-rearing events and increasing opportunities for consultation, as these are also related to maternal smoking. In addition, financial or gratuitous support for childcare, and an environment where mothers can raise their children while working should be promoted throughout the region; this will ensure that pregnant women with poor economic status may also raise children properly. Only a few studies have shown the relation between maternal smoking during pregnancy and the characteristic of their living area [10]. In this study, we evaluated this association using nationwide data with an adequate number of pregnant women and using questionnaire surveys administered across 420 regions in the country. We also used sociodemographic data from the statistics bureau in Japan. Further, we used multilevel regression model to investigate the independent effect of individual factors and regional factors on maternal smoking during pregnancy. The validity of this model was improved by selecting variables from several factors with consideration of multicollinearity and Akaike's Information Criterion.

However, this study also has some limitations. First, we could not identify the number of cigarettes smoked in a day and in which pregnancy period they had smoked. Light and heavy smokers may have been analyzed similarly. Second, it was difficult to validate the self-reported smoking information. Pregnant women may conceal their smoking habits $[38,39]$ or may respond in the negative if they have smoked occasionally during pregnancy. Therefore, the prevalence of smoking among pregnant women may possibly be underestimated. However, the number of pregnant women who provided an incorrect response remains unclear. Third, there might have been regional factors that were not included in the analysis because national data are limited. A previous study has shown that the women's educational level affects the smoking behavior during pregnancy [19], but we could not use regional variables that reflect the educational level. In addition, regional SES might not have been investigated adequately. We included FSI in the regional variables, but FSI is strongly affected by the wealth of the municipality itself. Other indicators that directly reflect the residents' financial status such as average income should have been used.

Given that we used only Japanese data in this study, the results may not be generalizable to other countries. Further, we could not show the causal relationship between maternal smoking behavior and the factors found in this study. Further studies are needed to identify these relations by including variables that could not be used in this study, such as the educational level, SES, and social capital.

\section{Conclusions}

The existence of consultation partners, participation in local events for childrearing, and other six factors were significantly associated with maternal smoking behavior during pregnancy. At regional level, unemployment rate and number of nursery were significantly associated with those behaviors after adjusting with individual and regional factors. In areas where the unemployment rate is high or where the number of children is low, the development of a child-rearing environment and improvement of financial or gratuitous support for childcare may help prevent maternal smoking. 
Author Contributions: Conceptualization, T.O. and Z.Y.; Methodology, T.O.; Writing-original draft preparation, T.O.; Writing-review and editing, Y.A., R.S., H.Y., and Z.Y.; project administration, Z.Y. All authors have read and agreed to the published version of the manuscript.

Funding: This study was supported by Health and Labor Sciences Research Grants (\#19DA0301 sukoyaka-ippan-002 (Principal Investigator; Zentaro Yamagata)).

Acknowledgments: We thank the office staff at the Healthy Parents and Children 21 for their help in accessing the data.

Conflicts of Interest: The authors declare no conflict of interest.

\section{Appendix A}

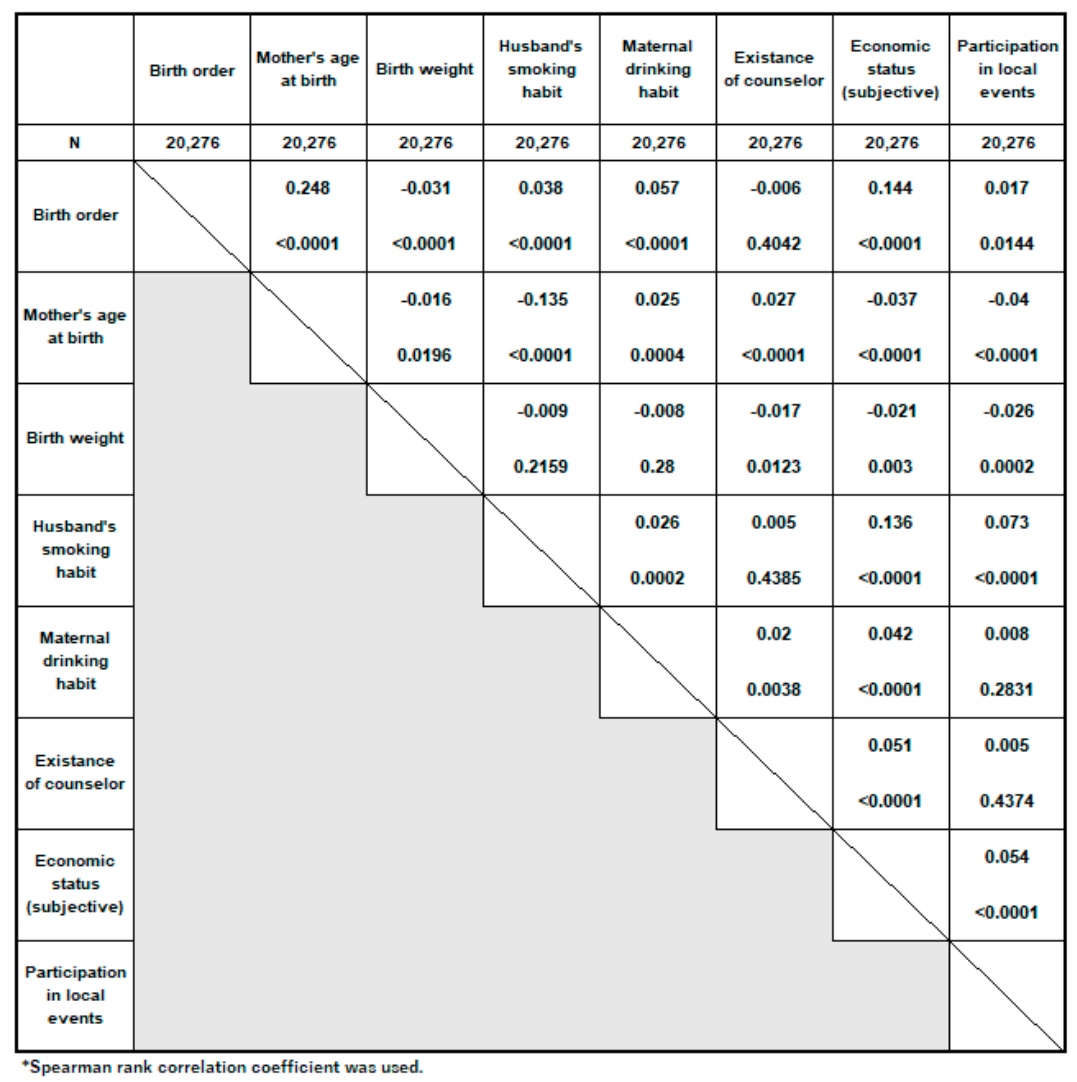

Figure A1. Coefficient of correlation between individual variables. 
Table A1. Multilevel logistic regression with stepwise (Model 1-Model 4).

\begin{tabular}{|c|c|c|c|c|c|c|}
\hline \multirow{2}{*}{ Variables } & \multirow{2}{*}{ Model 1} & \multicolumn{2}{|c|}{ Model 2} & \multicolumn{3}{|c|}{ Model 3-1 } \\
\hline & & OR & $95 \% \mathrm{CI}$ & OR & \multicolumn{2}{|c|}{$95 \% \mathrm{CI}$} \\
\hline \multicolumn{7}{|c|}{ Birth order } \\
\hline First & & & & ref. & & \\
\hline Second & & & & 1.026 & 0.845 & 1.247 \\
\hline Third & & & & 1.508 & 1.189 & 1.912 \\
\hline Fourth or more & & & & 3.076 & 2.284 & 4.142 \\
\hline \multicolumn{7}{|c|}{ Mother's age at birth } \\
\hline under 19 & & & & 3.538 & 2.109 & 5.937 \\
\hline age $20-24$ & & & & 2.354 & 1.843 & 3.006 \\
\hline age $25-29$ & & & & 1.164 & 0.94 & 1.443 \\
\hline age $30-34$ & & & & ref. & & \\
\hline age 35-39 & & & & 0.992 & 0.777 & 1.267 \\
\hline over 40 & & & & 1.263 & 0.832 & 1.918 \\
\hline \multicolumn{7}{|l|}{ Birth weight } \\
\hline under $2500 \mathrm{~g}$ & & & & 1.614 & 1.321 & 1.972 \\
\hline $2500-4000 \mathrm{~g}$ & & & & ref. & & \\
\hline over $4000 \mathrm{~g}$ & & & & 0.199 & 0.029 & 1.372 \\
\hline \multicolumn{7}{|c|}{ Economic status (subjective) } \\
\hline Very Good & & & & 0.75 & 0.421 & 1.334 \\
\hline Good & & & & 0.887 & 0.623 & 1.262 \\
\hline Normal & & & & ref. & & \\
\hline Poor & & & & 1.436 & 1.192 & 1.729 \\
\hline Very Poor & & & & 2.473 & 1.957 & 3.126 \\
\hline \multicolumn{7}{|c|}{$\begin{array}{l}\text { Husband's smoking habit during } \\
\text { pregnancy }\end{array}$} \\
\hline Yes & & & & 7.367 & 5.887 & 9.219 \\
\hline No & & & & ref. & & \\
\hline \multicolumn{7}{|c|}{ Drinking habit during pregnancy } \\
\hline Yes & & & & 3.988 & 3.063 & 5.193 \\
\hline No & & & & ref. & & \\
\hline \multicolumn{7}{|c|}{ Existance of counselor } \\
\hline Yes & & & & ref. & & \\
\hline No & & & & 2.048 & 1.39 & 3.017 \\
\hline
\end{tabular}


Table A1. Cont.

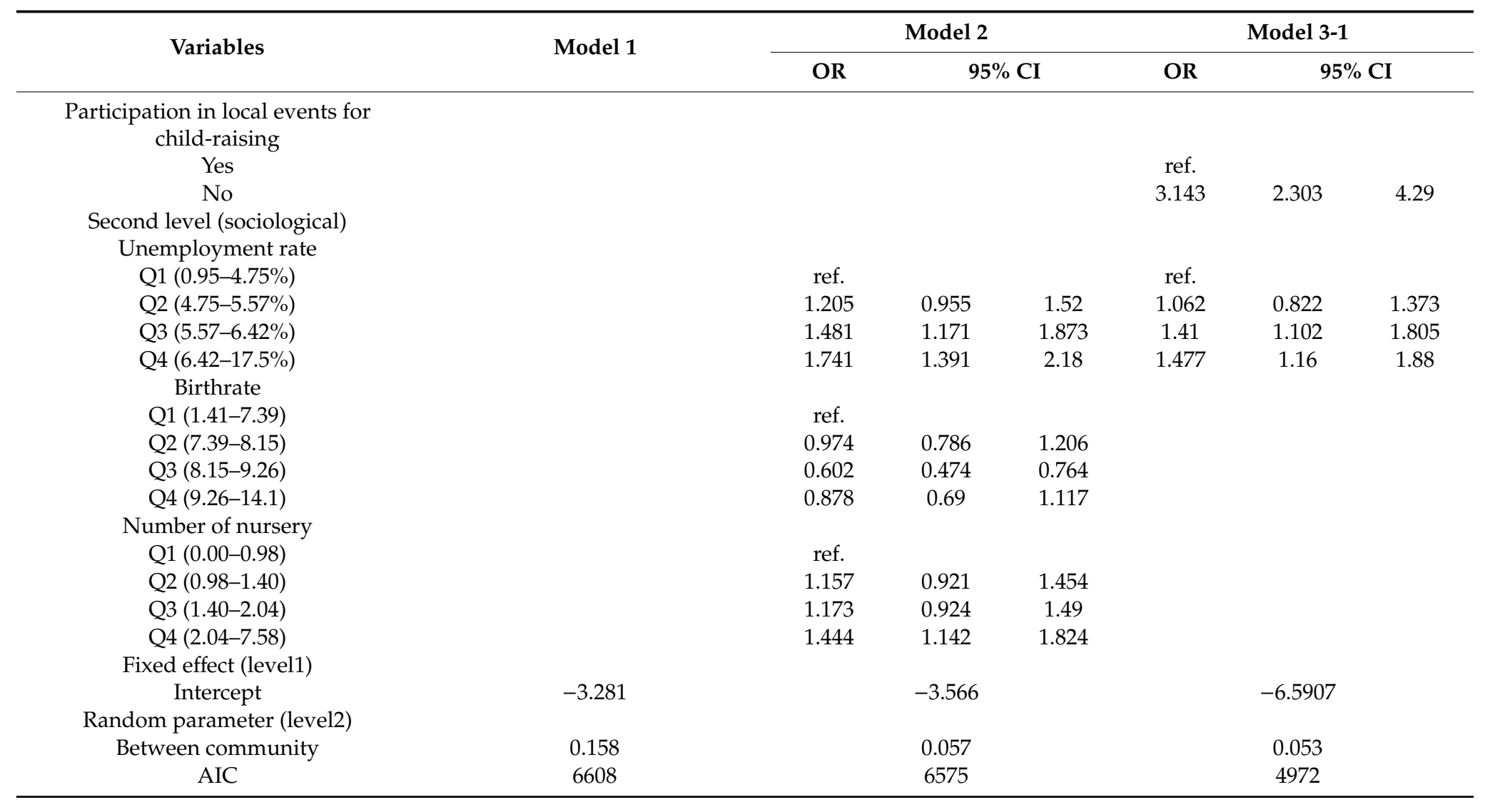


Table A1. Cont.

\begin{tabular}{|c|c|c|c|c|c|c|c|c|c|}
\hline \multirow{2}{*}{ Variables } & \multirow{2}{*}{\multicolumn{3}{|c|}{ Model 1}} & \multicolumn{3}{|c|}{ Model 2} & \multicolumn{3}{|c|}{ Model 3-1 } \\
\hline & & & & OR & & & OR & & \\
\hline \multirow{2}{*}{ Variables } & \multicolumn{3}{|c|}{ Model 3-2 } & \multicolumn{3}{|c|}{ Model 3-3 } & \multicolumn{3}{|c|}{ Model 4} \\
\hline & OR & \multicolumn{2}{|c|}{$95 \% \mathrm{CI}$} & & \multicolumn{2}{|c|}{$95 \% \mathrm{CI}$} & OR & \multicolumn{2}{|c|}{$95 \% \mathrm{CI}$} \\
\hline \multicolumn{10}{|l|}{ Birth order } \\
\hline First & ref. & & & ref. & & & ref. & & \\
\hline Second & 1.023 & 0.842 & 1.243 & 1.017 & 0.837 & 1.236 & 1.021 & 0.841 & 1.24 \\
\hline Third & 1.507 & 1.188 & 1.911 & 1.49 & 1.174 & 1.891 & 1.484 & 1.17 & 1.881 \\
\hline Fourth or more & 3.068 & 2.277 & 4.135 & 3.045 & 2.256 & 4.109 & 2.956 & 2.194 & 3.982 \\
\hline \multicolumn{10}{|c|}{ Mother's age at birth } \\
\hline under 19 & 3.478 & 2.072 & 5.837 & 3.46 & 2.06 & 5.809 & 3.563 & 2.126 & 5.972 \\
\hline age $20-24$ & 2.339 & 1.831 & 2.988 & 2.335 & 1.828 & 2.984 & 2.318 & 1.816 & 2.96 \\
\hline age $25-29$ & 1.155 & 0.932 & 1.432 & 1.152 & 0.929 & 1.428 & 1.158 & 0.934 & 1.435 \\
\hline age $30-34$ & ref. & & & ref. & & & ref. & & \\
\hline age $35-39$ & 0.978 & 0.766 & 1.249 & 0.979 & 0.767 & 1.251 & 0.991 & 0.777 & 1.265 \\
\hline over 40 & 1.309 & 0.863 & 1.985 & 1.293 & 0.851 & 1.964 & 1.294 & 0.853 & 1.963 \\
\hline $\begin{array}{l}\text { Birth weight } \\
\text { under } 2500 \mathrm{~g} \\
2500-4000 \mathrm{~g}\end{array}$ & $\begin{array}{l}1.608 \\
\text { ref. }\end{array}$ & 1.316 & 1.964 & $\begin{array}{l}1.608 \\
\text { ref. }\end{array}$ & 1.315 & 1.964 & $\begin{array}{c}1.601 \\
\text { ref. }\end{array}$ & 1.311 & 1.955 \\
\hline over $4000 \mathrm{~g}$ & 0.21 & 0.031 & 1.433 & 0.192 & 0.026 & 1.391 & 0.209 & 0.03 & 1.442 \\
\hline \multicolumn{10}{|c|}{ Economic status (subjective) } \\
\hline Very Good & 0.761 & 0.428 & 1.354 & 0.752 & 0.422 & 1.338 & 0.752 & 0.423 & 1.338 \\
\hline Good & 0.869 & 0.611 & 1.238 & 0.87 & 0.611 & 1.239 & 0.885 & 0.622 & 1.26 \\
\hline Normal & ref. & & & ref. & & & ref. & & \\
\hline Poor & 1.438 & 1.194 & 1.731 & 1.433 & 1.19 & 1.726 & 1.441 & 1.197 & 1.735 \\
\hline Very Poor & 2.465 & 1.949 & 3.116 & 2.472 & 1.954 & 3.127 & 2.493 & 1.974 & 3.15 \\
\hline \multicolumn{10}{|c|}{$\begin{array}{l}\text { Husband's smoking habit during } \\
\text { pregnancy }\end{array}$} \\
\hline Yes & 7.333 & 5.859 & 9.178 & 7.332 & 5.858 & 9.177 & 7.294 & 5.829 & 9.126 \\
\hline No & ref. & & & ref. & & & ref. & & \\
\hline \multicolumn{10}{|c|}{ Drinking habit during pregnancy } \\
\hline Yes & 3.937 & 3.021 & 5.132 & 4.011 & 3.075 & 5.231 & 3.959 & 3.041 & 5.155 \\
\hline No & ref. & & & ref. & & & ref. & & \\
\hline \multicolumn{10}{|c|}{ Existance of counselor } \\
\hline Yes & ref. & & & ref. & & & ref. & & \\
\hline No & 2.057 & 1.394 & 3.034 & 2.093 & 1.418 & 3.091 & 2.025 & 1.375 & 2.984 \\
\hline \multicolumn{10}{|c|}{$\begin{array}{l}\text { Participation in local events for } \\
\text { child-raising }\end{array}$} \\
\hline Yes & ref. & & & ref. & & & ref. & & \\
\hline No & 3.236 & 2.371 & 4.415 & 3.242 & 2.375 & 4.424 & 3.166 & 2.32 & 4.32 \\
\hline
\end{tabular}


Table A1. Cont.

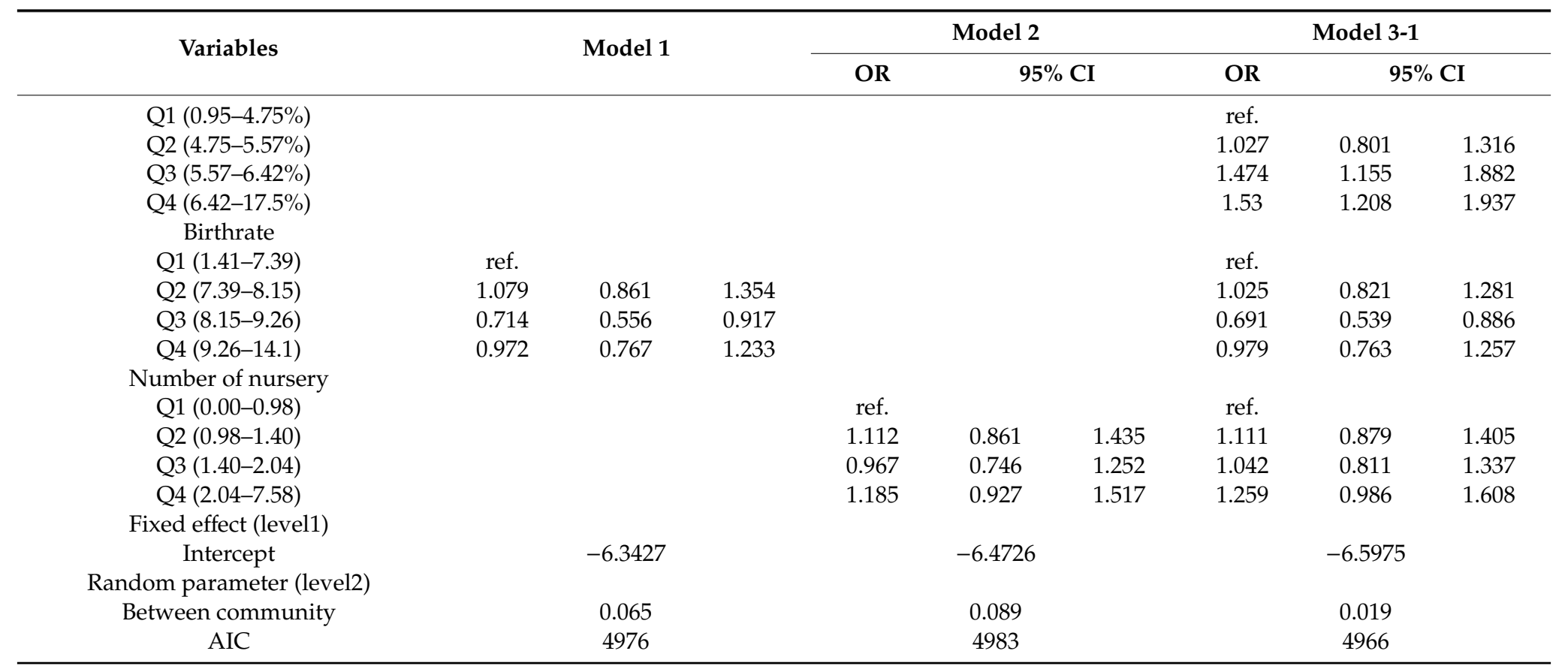




\section{References}

1. Reeves, S.; Bernstein, I. Effects of maternal tobacco-smoke exposure on fetal growth and neonatal size. Expert Rev. Obstet. Gynecol. 2008, 3, 719-730. [CrossRef] [PubMed]

2. Baba, S.; Wikstrom, A.K.; Stephansson, O.; Cnattingius, S. Influence of smoking and snuff cessation on risk of preterm birth. Eur. J. Epidemiol. 2012, 27, 297-304. [CrossRef] [PubMed]

3. Heaman, M.; Kingston, D.; Chalmers, B.; Sauve, R.; Lee, L.; Young, D. Risk factors for preterm birth and small-for-gestational-age births among Canadian women. Paediatr. Perinat. Epidemiol. 2013, 27, 54-61. [CrossRef] [PubMed]

4. Cnattingius, S. The epidemiology of smoking during pregnancy: Smoking prevalence, maternal characteristics, and pregnancy outcomes. Nicotine Tob. Res. 2004, 6 (Suppl. 2), S125-S140. [CrossRef]

5. Swanson, J.M.; Entringer, S.; Buss, C.; Wadhwa, P.D. Developmental origins of health and disease: Environmental exposures. Semin. Reprod. Med. 2009, 27, 391-402. [CrossRef] [PubMed]

6. World Health Organization. WHO Recommendations for the Prevention and Management of Tobacco Use and Second-Hand Smoke Exposure in Pregnancy; WHO: Geneva, Switzerland, 2013.

7. Balwicki, L.; Smith, D.M.; Pierucka, M.; Goniewicz, M.L.; Zarzeczna-Baran, M.; Jedrzejczyk, T.; Strahl, M.; Zdrojewski, T. Factors Associated With Quitting Among Smoking Pregnant Women From Small Town and Rural Areas in Poland. Nicotine Tob. Res. Off. J. Soc. Res. Nicotine Tob. 2017, 19, 647-651. [CrossRef]

8. Perkins, K.A. Smoking cessation in women. Special considerations. CNS Drugs 2001, 15, 391-411. [CrossRef]

9. Mittiga, C.; Ettridge, K.; Martin, K.; Tucker, G.; Dubyna, R.; Catcheside, B.; Scheil, W.; Maksimovic, L. Sociodemographic correlates of smoking in pregnancy and antenatal-care attendance in Indigenous and non-Indigenous women in South Australia. Aust. J. Prim. Health 2016, 22, 452-460. [CrossRef]

10. Sellstrom, E.; Arnoldsson, G.; Bremberg, S.; Hjern, A. The neighbourhood they live in: Does it matter to women's smoking habits during pregnancy? Health Place 2008, 14, 155-166. [CrossRef]

11. Moussa, K.M.; Ostergren, P.O.; Eek, F.; Kunst, A.E. Are time-trends of smoking among pregnant immigrant women in Sweden determined by cultural or socioeconomic factors? BMC Public Health 2010, 10, 374. [CrossRef]

12. Kharkova, O.A.; Krettek, A.; Grjibovski, A.M.; Nieboer, E.; Odland, J.O. Prevalence of smoking before and during pregnancy and changes in this habit during pregnancy in Northwest Russia: A Murmansk county birth registry study. Reprod. Health 2016, 13, 18. [CrossRef] [PubMed]

13. Oskarsdottir, G.N.; Sigurdsson, H.; Gudmundsson, K.G. Smoking during pregnancy: A population-based study. Scand. J. Public Health 2017, 45, 10-15. [CrossRef] [PubMed]

14. Vardavas, C.I.; Patelarou, E.; Chatzi, L.; Roumeliotaki, T.; Sarri, K.; Murphy, S.; Koutis, A.; Kafatos, A.G.; Kogevinas, M. Factors associated with active smoking, quitting, and secondhand smoke exposure among pregnant women in Greece. J. Epidemiol. 2010, 20, 355-362. [CrossRef] [PubMed]

15. Kramer, M.S.; Seguin, L.; Lydon, J.; Goulet, L. Socio-economic disparities in pregnancy outcome: Why do the poor fare so poorly? Paediatr. Perinat. Epidemiol. 2000, 14, 194-210. [CrossRef] [PubMed]

16. Spencer, N.; Logan, S. Sudden unexpected death in infancy and socioeconomic status: A systematic review. J. Epidemiol. Community Health 2004, 58, 366-373. [CrossRef]

17. Balwicki, L.; Zarzeczna-Baran, M.; Wierucki, L.; Jedrzejczyk, T.; Strahl, M.; Wrotkowska, M.; Goniewicz, M.L.; Zdrojewski, T. Smoking among pregnant women in small towns in Poland. Int. J. Public Health 2016, 61, 111-118. [CrossRef]

18. Baron, R.; Mannien, J.; de Jonge, A.; Heymans, M.W.; Klomp, T.; Hutton, E.K.; Brug, J. Socio-demographic and lifestyle-related characteristics associated with self-reported any, daily and occasional smoking during pregnancy. PLoS ONE 2013, 8, e74197. [CrossRef]

19. Ergin, I.; Hassoy, H.; Tanik, F.A.; Aslan, G. Maternal age, education level and migration: Socioeconomic determinants for smoking during pregnancy in a field study from Turkey. BMC Public Health 2010, 10, 325. [CrossRef]

20. Humphrey, G.; Rossen, F.; Walker, N.; Bullen, C. Parental smoking during pregnancy: Findings from the Growing Up in New Zealand cohort. N. Z. Med. J. 2016, 129, 60-74.

21. Jhun, H.J.; Seo, H.G.; Lee, D.H.; Sung, M.W.; Kang, Y.D.; Syn, H.C.; Jun, J.K. Self-reported smoking and urinary cotinine levels among pregnant women in Korea and factors associated with smoking during pregnancy. J. Korean Med. Sci. 2010, 25, 752-757. [CrossRef] 
22. Mohsin, M.; Bauman, A.E.; Forero, R. Socioeconomic correlates and trends in smoking in pregnancy in New South Wales, Australia. J. Epidemiol. Community Health 2011, 65, 727-732. [CrossRef] [PubMed]

23. Moore, E.; Blatt, K.; Chen, A.; Van Hook, J.; DeFranco, E.A. Factors Associated with Smoking Cessation in Pregnancy. Am. J. Perinatol. 2016, 33, 560-568. [PubMed]

24. Nur, N. Association of risk factors with smoking during pregnancy among women of childbearing age: An epidemiological field study in Turkey. Sao Paulo Med. J. 2017, 135, 100-106. [CrossRef] [PubMed]

25. Smedberg, J.; Lupattelli, A.; Mardby, A.C.; Nordeng, H. Characteristics of women who continue smoking during pregnancy: A cross-sectional study of pregnant women and new mothers in 15 European countries. BMC Pregnancy Childbirth 2014, 14, 213. [CrossRef] [PubMed]

26. Suzuki, K.; Shinohara, R.; Sato, M.; Otawa, S.; Yamagata, Z. Association Between Maternal Smoking During Pregnancy and Birth Weight: An Appropriately Adjusted Model From the Japan Environment and Children's Study. J. Epidemiol. 2016, 26, 371-377. [CrossRef]

27. Voidazan, S.; Tarcea, M.; Abram, Z.; Georgescu, M.; Marginean, C.; Grama, O.; Buicu, F.; Ruta, F. Associations between lifestyle factors and smoking status during pregnancy in a group of Romanian women. Birth Defects Res. 2018, 110, 519-526. [CrossRef]

28. Xu, X.; Rao, Y.; Wang, L.; Liu, S.; Guo, J.J.; Sharma, M.; Zhao, Y. Smoking in pregnancy: A cross-sectional study in China. Tob. Induc. Dis. 2017, 15, 35. [CrossRef]

29. Dyal, S.R.; Valente, T.W. A Systematic Review of Loneliness and Smoking: Small Effects, Big Implications. Subst. Use Misuse 2015, 50, 1697-1716. [CrossRef]

30. Wang, Q.; Shen, J.J.; Cochran, C. Unemployment Rate, Smoking in China: Are They Related? Int. J. Environ. Res. Public Health 2016, 13, 113. [CrossRef]

31. Broz, J.; Brabec, M.; Zdarska, D.J.; Novotna, M.; Kvapil, M. Incidence of Diabetes Mellitus Narrowly Correlates with Unemployment Rate during 2000-2012 in the Czech Republic. Cent. Eur. J. Public Health 2016, 24, 86-87. [CrossRef]

32. Bender, A.M.; Kawachi, I.; Jorgensen, T.; Pisinger, C. Neighborhood deprivation is strongly associated with participation in a population-based health check. PLoS ONE 2015, 10, e0129819. [CrossRef] [PubMed]

33. Bender, A.M.; Kawachi, I.; Jorgensen, T.; Pisinger, C. Neighborhood social capital is associated with participation in health checks of a general population: A multilevel analysis of a population-based lifestyle intervention- the Inter99 study. BMC Public Health 2015, 15, 694. [CrossRef] [PubMed]

34. Flor, C.R.; Baldoni, N.R.; Aquino, J.A.; Baldoni, A.O.; Fabbro, A.L.D.; Figueiredo, R.C.; Oliveira, C.D.L. What is the association between social capital and diabetes mellitus? A systematic review. Diabetes Metab. Syndr. 2018, 12, 601-605. [CrossRef] [PubMed]

35. Lindstrom, M.; Axelsson, J.; Moden, B.; Rosvall, M. Sexual orientation, social capital and daily tobacco smoking: A population-based study. BMC Public Health 2014, 14, 565. [CrossRef] [PubMed]

36. Paul, S.; Adler, S.-W.K. Social Capital: Prospects for a New Concept. Acad. Manag. Rev. 2002, 27, 17-40.

37. Quality-of-Life Policy Bureau Cabinet Office. Government of Japan, Social Capital: Looking for a Virtuous Circle of Rich Human Relations and Civic Activities (Japanese); Cabinet: Tokyo, Japan, 2003.

38. Ford, R.P.; Tappin, D.M.; Schluter, P.J.; Wild, C.J. Smoking during pregnancy: How reliable are maternal self reports in New Zealand? J. Epidemiol. Community Health 1997, 51, 246-251. [CrossRef] [PubMed]

39. Klebanoff, M.A.; Levine, R.J.; Clemens, J.D.; DerSimonian, R.; Wilkins, D.G. Serum cotinine concentration and self-reported smoking during pregnancy. Am. J. Epidemiol. 1998, 148, 259-262. [CrossRef]

(C) 2019 by the authors. Licensee MDPI, Basel, Switzerland. This article is an open access article distributed under the terms and conditions of the Creative Commons Attribution (CC BY) license (http://creativecommons.org/licenses/by/4.0/). 